\title{
Innovative technologies in using Baltic amber for wellness
}

Authors' Contribution:

A Study Design

B Data Collection

C Statistical Analysis

D Data Interpretation

E Manuscript Preparation

F Literature Search

G Funds Collection

\author{
Anna Mikhaylova ${ }^{1}$ ABDEF, Andrey Mikhaylov2, 3 ABDEF \\ ${ }^{1}$ Institute of Environmental Management, Urban Development and Spatial Planning, \\ Immanuel Kant Baltic Federal University, Kaliningrad, Russian Federation \\ ${ }^{2}$ Innovation Geography Laboratory, Regional Studies Institute, \\ Immanuel Kant Baltic Federal University, Kaliningrad, Russian Federation \\ 3 Institute of Innovation Design and Technological Entrepreneurship, \\ Saint Petersburg Electrotechnical University «LET|», St. Petersburg, Russian Federation
}

\section{abstract}

Background: The aim is to identify novel methods and demand in using amber and its products in the field of medicine, health preservation and medical tourism.

Material and methods:

Quantitative and qualitative analysis is done on patents and patent applications indicating the use of natural amber and its derivatives as reflected in the title and/or abstract sections. Data is analyzed by 4 dimensions: temporal, sectoral, territorial, institutional. The study period covers 1975-2020. Data source is the Dimensions patents database.

Results: The development of technologies for using or processing amber and its derivatives is characterized by low and unstable patent activity. The majority of patents are generated at the regions with amber deposits. Wellness specialization is found to be an important technology driver, although outperformed by jewelry production and processing technologies. The WIPO plays a significant role in protecting the amber related innovations in wellness.

Conclusions: The patenting activity for amber processing technologies is low, including in the field of medicine, health preservation and medical tourism. Cross-border networking between Russia (primarily the Kaliningrad region), Poland, Lithuania, and Germany can positively affect the development of Baltic amber cluster, boosting the demand for high-tech processing of amber and expanding its application in wellness.

Key words: natural amber, Baltic amber, succinite, innovative health technologies, amber patent.

\section{article details}

Article statistics: Word count: 3,616; Tables: 2; Figures: 3; References: 33

Received: June 2020; Accepted: August 2020; Published: November 2020

Full-text PDF: http://www.balticsportscience.com

Copyright $\odot$ Gdansk University of Physical Education and Sport, Poland

Indexation: Celdes, Clarivate Analytics Emerging Sources Citation Index (ESCI), CNKI Scholar (China National Knowledge Infrastructure), CNPIEC, De Gruyter - IBR (International Bibliography of Reviews of Scholarly Literature in the Humanities and Social Sciences), De Gruyter - IBZ (International Bibliography of Periodical Literature in the Humanities and Social Sciences), DOAJ, EBSCO - Central \& Eastern European Academic Source, EBSCO - SPORTDiscus, EBSCO Discovery Service, Google Scholar, Index Copernicus, J-Gate, Naviga (Softweco, Primo Central (ExLibris), ProQuest - Family Health, ProQuest - Health \& Medical Complete, ProQuest - Illustrata: Health Sciences, ProQuest - Nursing \& Allied Health Source, Summon (Serials Solutions/ProQuest, TDOne (TDNet), Ulrich's Periodicals Directory/ulrichsweb, WorldCat (OCLC)

Funding: Andrey Mikhaylov expresses gratitude to the RFBR for funding the research project No. 18-310-20016 “Coastal cities in innovation spaces of the European part of Russia".

Conflict of interests: Authors have declared that no competing interest exists.

Corresponding author: Avdrey Mikhaylov A. Nevskogo 14 Str., 236014, Kaliningrad, Kaliningrad Region, Russia; e-mail: mikhailov.andrey@ yahoo.com

Open Access License: This is an open access article distributed under the terms of the Creative Commons Attribution-Non-Commercial-NoDerivatives 4.0 International (https://creativecommons.org/licenses/by-nc-nd/4.0/), which permits use, distribution and reproduction in any medium, provided the original work is properly cited, the use is non-commercial and is otherwise in compliance with the license. 


\section{INTRODUCTION}

Amber is one of the organic minerals widely used in long-distance international trade from the Early Bronze Age [1]. In the terminology of mineralogical sciences, amber is referred to as "succinite" and is a generic term for any fossilized natural resin (from the Latin "sucinum" - tree juice or wood resin [2]). For many years, it was believed that the Baltic Sea basin is the only source of amber, which led to the consolidation of the words "amber" and "Baltic amber" as synonyms for succinite and the only "genuine amber" [3-5]. Today we know about dozens of amber deposits around the world - the largest on the Sambian Peninsula in the Kaliningrad Region of Russia, and more modest one on Sakhalin Island and the Commander Islands of the Kamchatka Territory of Russia, in Poland and the Baltic States, Ukraine, Belarus, Germany, Denmark, Sweden, Spain, Italy on the island of Sicily, Romania, Mexico, in the USA on the peninsula of Alaska, on the Arabian Peninsula, on the island of Borneo, the Dominican Republic and others [5]. These deposits differ not only in the volume of amber deposits, but also in the depth to bedrock, which affects the mining methods. The oldest and most primitive method of amber extraction on the Baltic Sea coast is manual gathering on beaches and shallows where amber was washed off by the sea, as well as amber fishing with a net. Amber fishing remains as a method of illegal mining and as a factor of tourism development with amber becoming increasing popular around the globe [6-9].

Amber is commercially mined in Russia in open pit mining at the coastal zone as well as directly on the seashore, using pumped water to wash sand and soil, mainly the blue soil - sand and clay of marine origin (Kaliningrad Regional Amber Museum: https://www. ambermuseum.ru/en/home/about_amber/extraction). The Primorskoye (Palmnicken) deposit in the village of Yantarny at the Kaliningrad region of Russia is unmatched not only in the explored reserves and world production volumes - about $90 \%$, but also in gem concentration (on average of $2 \mathrm{~kg} / \mathrm{m}^{3}$ and up to $4.5 \mathrm{~kg} / \mathrm{m}^{3}$ based on different estimations) [10-17]. Other deposits are characterized by a significantly lower concentration of amber, its extremely uneven distribution in the deposits and a small fraction. For example, at the Vladimir Vostochny deposit in the Rivne region of Ukraine, the average amber content in the rock is $27.62 \mathrm{~g} / \mathrm{m}^{3}[14,15]$. With that, the total amber reserves in the Kiev, Zhytomyr, Volyn, Rivne, Kherson regions and in the Carpathian region of Ukraine are estimated at 100,000 tons $[18,19]$. Two amber-bearing regions are distinguished in Belarus: Polesskaya and Mikashevichsko-Zhitkovichi, with a maximum amber concentration of $110 \mathrm{~g} / \mathrm{m}^{3}$ and $33 \mathrm{~g} /$ $\mathrm{m}^{3}$, respectively [16]. Deposits located on the shores of Gdansk Bay and the Gulf and on the North Sea coast in the Netherlands, Germany and Denmark also have modest gem content (for example, in the Stubbenfelde field on the island of Usedom it is $0.357 \mathrm{~kg} / \mathrm{m}^{3}$ ) [16].

Differences in the depth of the rock, its fraction and concentration affect the extraction methods. In the Kaliningrad region of Russia, a quarry method is used for the extraction of amber, with the development of deposits by dredgers and with the use of hydraulic monitors on an area of more than $5 \mathrm{~km}^{2}$ [10]. In Ukraine, the main extraction of amber is carried out by mechanical or hydraulic methods, but is illegal, with an increase in its area [20,21]. The deposits located in Poland are small and unsuitable for systematic industrial production [22, 23]. In the Greater Antilles, Dominican blue amber is mined via bell pit digging [24]. The Dominican amber factory is the second largest in the world and has a number of very small mines, but it is also not comparable with the volumes of the Kaliningrad Amber Plant [13].

Thus, the issue of increasing the volume, technologicalization of the process and deepening the industrial processing of amber is of great importance for the economy of the Kaliningrad region of Russia as well as of interest to other countries with amber deposits. The development of high-tech methods for amber processing will radically change the amount of value added and expand network of value chains. Most of the deep amber processing methods involve the use of heavily crushed stone, which will solve the problem of accumulating a significant amount of unused small-grained waste from the Kaliningrad Amber Plant. 
One of the promising areas for the deep processing of amber of high value added is its use in medicine and recreation. For centuries, amber in the form of unprocessed pieces, powder, compressed, ointments or tinctures has been used to treat many diseases: from diseases of a bacterial origin to rheumatic diseases and diseases of the nervous system $[24,26]$. The first mention of the healing properties of amber and its use in medicine belongs to the famous ancient physician Hippocrates (460-377 BC) [19]. The continued medical application of amber has been documented over the centuries [2]. In folk medicine, succinitis is considered a cure for a variety of diseases. Among the useful properties of amber, which have found application in folk medicine are antioxidant, antimicrobial, anti-inflammatory, repellent and insecticidal features [27]. The research results show that the application of varnish using amber processing waste prevents the growth of bacteria, aquatic organisms and other microorganisms in aggressive environments. These technologies can be used both for engineering purposes to prevent rust, and in medicine to create a protective layer on prostheses and other medical devices [28-31].

To date, the research of scientists from Poland, Russia and the Baltic states is more focused on amber as a factor in the development of the tourist potential of the territory, while most researchers ignore this area of research whatsoever. Now the demand for small-fraction raw amber is low due to the underdeveloped market of high-tech amber processing. In turn, this does not stimulate the world's leading Kaliningrad Amber Plant to invest in the production and supply of the world market with raw materials that fall beyond the criteria of the jewelry industry. However, the Kaliningrad region of the Russian Federation achieved certain advances in the development of the amber industry, including in the sphere of wellness tourism (amber SPA procedures, sensory amber rooms, amber cosmetics, foods and drinks with a healing effect, etc.).An initiative to create an amber cluster is being implemented in the region. The Kaliningrad Amber Cluster was included in the federal register of industrial clusters providing all of its participants with state support in 2019 [32]. It is also closely linked to the emerging tourism cluster in the region, potentially cross-border with the EU [33]. The purpose of this article is to assess the variety of healthrelated amber products, as well as analyze the global demand for innovative technologies for the use of Baltic amber in wellness.

\section{MATERIAL AND METHODS}

To analyze the existing modern technologies for the use of Baltic amber in the field of medicine, health conservation and recreation (medical tourism), we use the method of patent analysis. Firstly, patents are a registerable, and therefore amenable to analysis, marker that indicates the development of a new technology. Secondly, the presence of patents in a specific field indicates a research interest and ongoing practice-oriented developments, and their number reflects the relevance of $R \& D$ data. The source of patent information is the largest specialized international database Dimensions of the Digital Science, which has built-in analytical toolkit. The research period covers 45 years - from 1975 till present. The large scope is determined by a significant lag existing between patenting a technology and its commercial application. Search by patent data is carried out by patent title and abstract. The request includes phrases reflecting different types of natural amber and methods of processing it. The technologies for the production and use of artificial amber are not considered, since the focus of the study is on the use of raw Baltic amber, the main reserves of which are concentrated in three deposits of the Kaliningrad region of Russia, as well as in small deposits of Poland and Lithuania. This is a compiled request: "amber grain" OR "amber waste" OR "amber article" OR "amber bead" OR "amber chips" OR "amber coating" OR "amber composite" OR "amber cream" OR "amber crumb" OR "amber dust" OR "amber extract" OR "amber lacquer" OR "amber meal" OR "amber nugget” OR "amber oil” OR "amber polish" OR "polished amber" OR "polishing amber" OR 
"amber product" OR "amber soap" OR "amber-based varnish" OR "amber-containing" OR "amber therapy" OR "Baltic amber" OR "bonded amber" OR "doublets amber" OR "cutting amber" OR "extract of amber" OR "filler from amber" OR "filling-amber" OR "finishing amber" OR "grinding amber" OR "hard amber" OR "machined amber" OR "made of amber" OR "modified amber" OR "natural amber" OR "powder amber" OR "pressed amber" OR "raw amber" OR "reconstructed amber" OR "refined amber" OR "amber nuggets" OR "amber granulate" OR "stone of amber" OR "turning amber" OR "using the amber" OR "amber processing" OR "natural artisan amber" OR "modified amber" OR "reconstructed amber" OR "varnish amber" OR "unprocessed amber" OR "melted amber" OR "heat-enhanced amber" OR "bonded amber" OR "genuine amber" OR "amber products".

A total set of 225 patent records are discovered that are filed from 1975 to 2020. The database was unloaded in May 2020. According to the assessment results of the actual contents of the patents, 66 entries are excluded as not related to the processing of minerals - amber. The sample comprised 159 patent records and 140 unique technologies (for some developments, the database contained several patent records with different statuses). Table 1 presents 4 areas of analysis implemented in this study, and also explains what the research focus was focused on and what indicators were used.

Table 1. Methodological approach to the study of existing modern technologies for the use and processing of Baltic amber

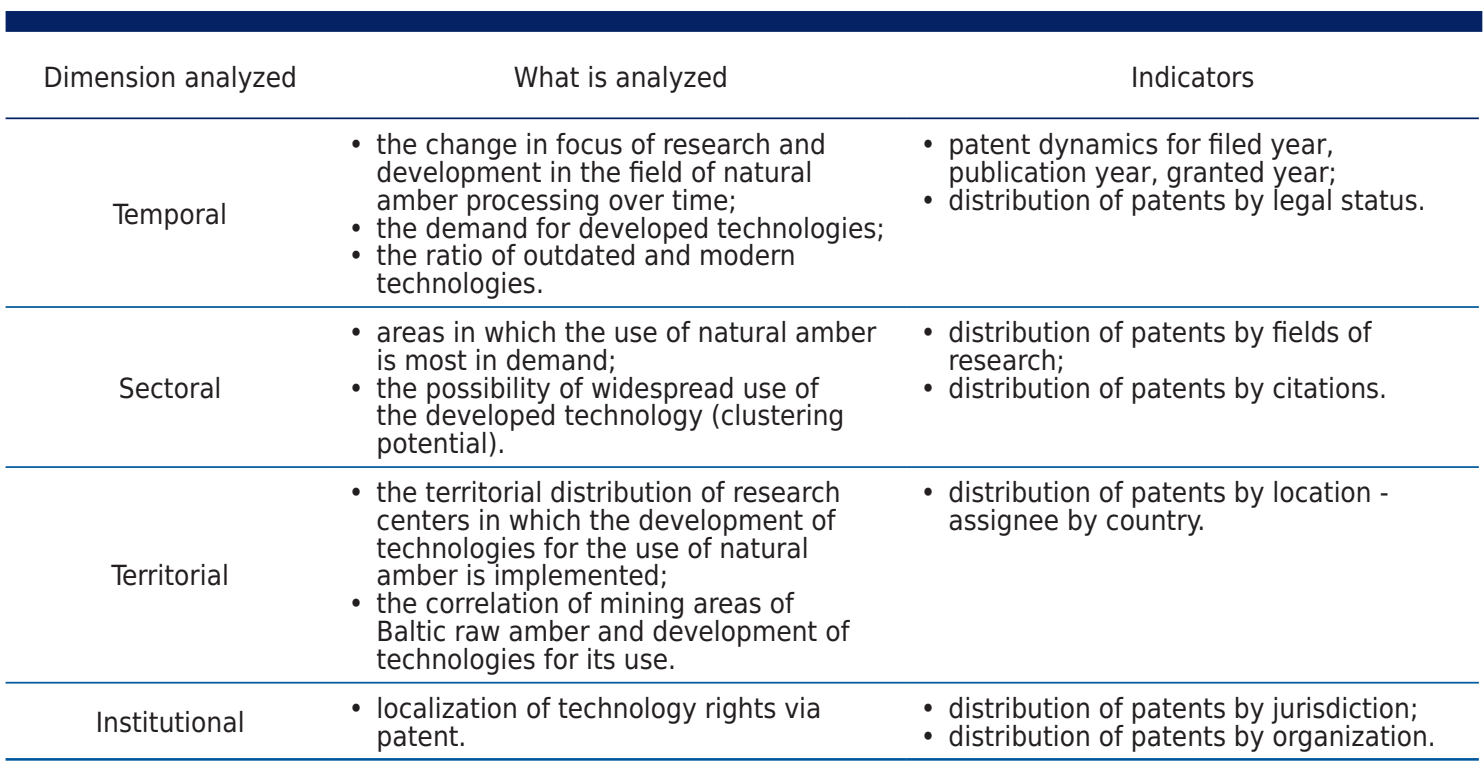

In order to analyze the current modern technologies for the use and processing of Baltic amber directly in the field of medicine, health conservation and medical recreation and the ratio of their share relative to the total number of technologies for using natural amber, an additional sampling within the 140 patent records was carried out by conducting a content analysis of the abstracts of patent applications. The thematic patent base formed in this way amounted to 41 entries from technologies that have the potential for use in the fields of medicine, health conservation and medical recreation, but are not necessarily directly related to the field of research "Medical and Health Sciences". These patents are hereinafter referred to as wellness patents.

\section{RESULTS}

The results of the temporal analysis of the distribution of the sample of patents demonstrate the unstable dynamics of patent, and, therefore, inventive activity in the use of natural 
amber against the background of a relatively small number of patent records themselves (Table 2). Wellness accounts for slightly less than $29 \%$ of all patent records in the sample, and their dynamics follows the trend for all patent samples over the years. The most active research interest in the field of wellness for using amber in the period under review was 2000-2009, which reflects the distribution by filed year. In 2010-2019 the number of new patent entries in the Dimensions database in the area of wellness has almost halved: from 22 to 13 units, amid a general decline in patent activity by 1.6 times.

Table 2. Dynamics of patents in the use of natural amber, units

\begin{tabular}{llccccccc}
\hline \multirow{2}{*}{ Year } & Patents & $1974-$ & $1985-$ & $1990-$ & $2000-$ & $2010-$ & $2020-$ & $2030-$ \\
& & 1984 & 1989 & 1999 & 2009 & 2019 & 2029 & - \\
\hline \multirow{2}{*}{ filed } & total & 1 & 2 & 13 & 76 & 48 & - & - \\
\hline \multirow{2}{*}{ publication } & wellness & 0 & 1 & 4 & 22 & 13 & - & - \\
& total & 1 & 1 & 9 & 76 & 52 & 1 & - \\
\hline \multirow{2}{*}{ granted } & wellness & 0 & 0 & 5 & 19 & 15 & 1 & - \\
& total & 1 & 0 & 2 & 14 & 10 & - & - \\
\hline \multirow{2}{*}{ expiration } & wellness & 0 & 0 & 0 & 5 & 4 & - & 4 \\
& total & 0 & 0 & 1 & 0 & 12 & 7 & 4 \\
\hline
\end{tabular}

Source: Dimensions database

Legal status shows the possibility of using a patent and its monetization. The wellness technologies are characterized by the following ratio of active, granted and inactive patents: 5/65/30\%, as presented in Figure 1 . In other words, only $5 \%$ of these patents are currently applicable. A similar situation exists in other niches, where most of the developed technologies for using amber are practically not protected by patents for various reasons: the patent has expired, fees for maintaining the patent have not been paid, patents have been abandoned and others.

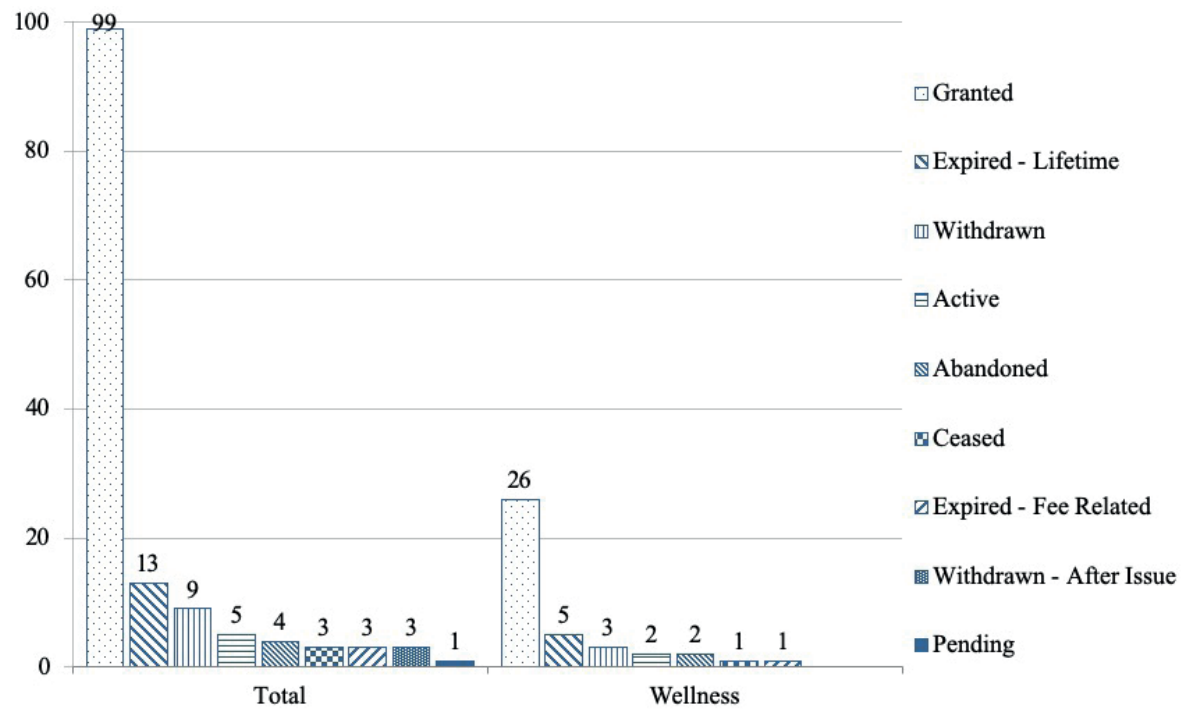

Fig. 1. Distribution of patents in the use of natural amber by legal status

Source: Dimensions database

An indicator of the demand for developments in the technological use of amber is the level of their citation. Only 22 units or $15.7 \%$ of the patents in the sample are cited at least once. For the wellness group of patents, this indicator is slightly higher $-17.5 \%$ of 40 patents have citations. Moreover, among all cited patents of the sample, 31.8\% accounted for 
wellness. Most cited amber patents have 5 or less citations. Only 4 patents of the sample have a citation rate of 7 to 24 times, of which 2 are wellness patents.

The distribution of wellness patents by fields of research shows the diversity of research areas in which amber research results can find further application (e.g. in the fields of medicine, health preservation and medical recreation) - Fig. 2. The data indicates a good potential for the clustering of research and economic activities in the field of amber.

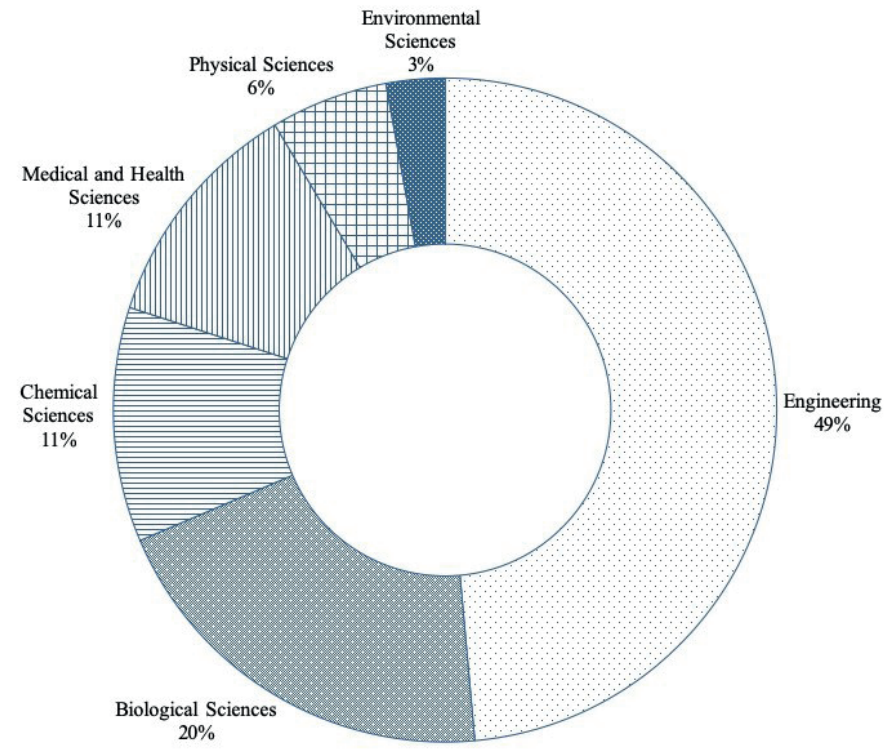

Fig. 2. Distribution of patents in the field of wellness using natural amber by fields of research

Source: Dimensions database

The largest volume of wellness patents is in the field of engineering research at the interface with Physical sciences and Environmental sciences. This includes developments in the field of therapy and physiotherapy (e.g., physiotherapy table, physiotherapy complex, local physiotherapy devices, therapeutic air ionization cabinet, actively heated physiotherapeutic product with amber filling, etc.), improvement in medical equipment, materials and tools (e.g. sheathing for catheters, amber composite fibers for the manufacture of textiles for surgical purposes, amber-based hygiene material, amber gel, device for protecting human being against electric instrument radiation and others), the production of amber products with useful properties (for example, rubber bands for hair against head lice, teethers for children's teeth, amber insoles for shoes, etc.). The generation of technologies in Biological sciences and Chemical sciences based on the study of the beneficial wellness properties of amber is mainly associated with the development of cosmetic and perfume compositions, aromatic compounds containing amber extract. These developments may be applicable in the manufacturing of creams, gels, lotions for skin care, perfumes and aromatherapy. Developments in Medical and Health sciences include various methods and therapeutic composition for the treatment (for diseases of muscles, joints, tendons and / or nerves; the need to affect a pathological focus or reflexogenic zone; to provide longterm prevention and improvement in diabetes and obesity, caused by a hyperglycemic symptom and a chronic increase in blood sugar, etc.).

In the territorial dimension, there can be distinguished two main centers for generating patents in the field of using amber both in the total number and in the wellness group: these are Russia and Germany, which together account for $75.7 \%$ of all patent records in the sample and $47.5 \%$ - wellness patents. The absolute leader is Russia with 78 patent 
entries, of which 10 are in the wellness sphere. The main Russian research centers for the study of amber are located in the Kaliningrad region (Kaliningrad), where amber is mined. Also, a number of developments are carried out in Krasnodar, Krasnoyarsk, Novosibirsk, Blagoveshchensk. In Germany, the most important research centers for the study of amber are organizations in Stuttgart and Hamburg, and separate studies have been carried out in Holzminden and Ludwigshafen am Rhein. The remaining $25 \%$ of patent records belong to another 11 countries: 6 from the United States, 5 from Japan, France, Lithuania, 4 from Taiwan, 3 from United Kingdom, 2 from Poland and Ukraine, 1 from Australia, Latvia, Mexico. An interesting trend should be noted, while for Russia and Germany the research areas on the wellness use of amber are not leading in the generation of patents in relative terms, for most other countries the wellness focus is the key (Fig. 3).

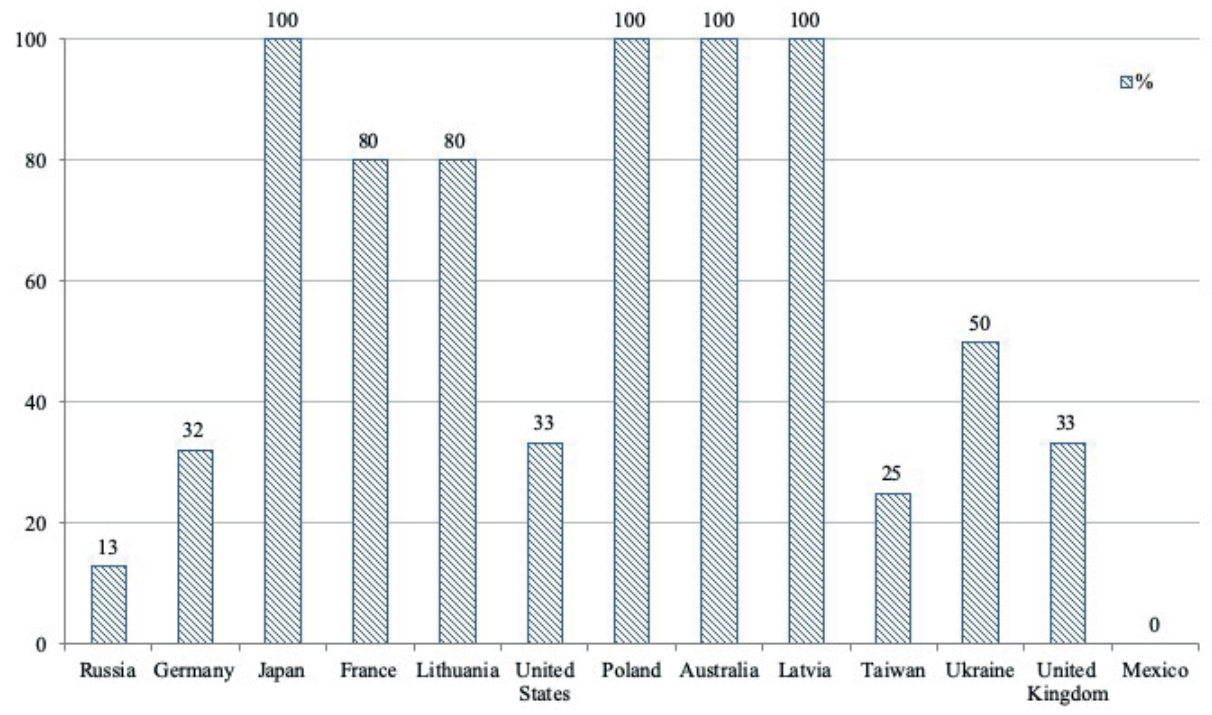

Fig. 3. Distribution of assignee countries by the proportion of wellness patents of the total number of patents of the country on the use of natural amber, \%

The institutional dimension of the distribution of patents by area of jurisdiction is as follows: 12 are listed in the World Intellectual Property Organization, 4 - in the European Patent Office, and the rest are 6 national patent offices (81 - Russia, 25 - Germany, 10 USA, 3 - Australia, 3 - France, 2 - Great Britain). The leadership of Russia is explained by its interest in the generation of technologies related to amber, as the country has its largest industrial deposits. However, most patents with jurisdiction of the Russian Federation relate to the manufacture of jewelry and artistic products and amber processing methods, wellness accounted for only $14.8 \%$ of the total number of patents filed with the National Patent Office of Russia. The World Intellectual Property Organization plays a significant role in the distribution of wellness patents by area of jurisdiction: 11 out of 12 patent applications filed in it belong to wellness.

\section{DISCUSSION}

The results of the analysis in four dimensions: temporal, sectoral, territorial and institutional, showed that patent activity in the use of natural amber has a certain traceable level of localization in traditional geographical areas of its production without a steady temporal growth trend, which indicates the instability of demand for these technologies. Perhaps this is due to the instability of amber production and the supply of raw materials to the global market, which does not allow amber-driven companies to build their long-term development strategies. Wellness focus in the development of amber technology is one of the most important along with jewelry and construction materials. Moreover, unlike the 
aforementioned areas, the wellness technologies are more predisposed to cross national borders, as can be seen from the distribution of wellness patents in the jurisdiction - along with national patent offices, a significant proportion of applications a re sent to WIPO. Wellness patents are characterized by a wide representation of research areas, which creates the conditions for the possibility of applying the developed technologies for the use of amber in different industries with the potential for clustering, for example, the production of medical equipment, textile and furniture industries, tourist infrastructure and collective accommodation facilities, medical clinics, production of medical cosmetics, health and spa centers, etc. This will create a demand for small fractions of amber that remain on the production of large nuggets but are now less required on the market. The amber industry can be a serious consumer of innovation with an active support to its development and creating a transparent system for regulating trade in amber and semi-finished products from it. However, at the moment, the market for innovative technologies for using amber is not ready for increased demand, and the number of active patents is small.

\section{CONCLUSIONS}

Having a long history of medical application [2, 25-27], our research suggests that amber still remains underestimated in the field of medicine, health conservation and recreation. This is confirmed by the unstable dynamics of patents in wellness and their small number, as well as a low share of active patents. At the same time, there is a high potential for the use of amber in the field of medicine, health conservation and recreation (medical tourism) with the formation of an amber cluster, which is associated with the possibility of a wide intersectoral profile of its application at the junction of several research areas: engineering, biological sciences, chemical sciences, medical and health sciences, physical sciences, environmental sciences. Based on the analysis of the geography of research and the jurisdiction of patents, as well as the location of amber deposits, we can conclude that there is a significant research, industrial, resource and recreational potential to create a crossborder Baltic amber cluster between Russia, Germany, Poland and Lithuania, specializing in wellness. It could be a new impulse for the generation of innovative technologies in this area. However, in modern conditions, the institutional factor [32, 33] is a significant obstacle to the implementation of this kind of initiative. At present, the demand for innovative technologies for the use of Baltic amber in wellness can be assessed as weak and fragmented in terms of geography. There are a number of innovative initiatives, for example, in the framework of creating an amber cluster in the Kaliningrad region of Russia; however, they do not form a global trend for health treatment with the help of amber.

\section{REFERENCES}

[1] Wells PS. Socio-economic aspects of the amber trade in Early Iron Age Slovenia. J Baltic Stud. 1985;16 (3):268-275. https://doi.org/10.1080/01629778500000171

[2] Ragazzi E. Amber, a stone of sun for ancient medicines. Acta medico-historica Rigensia. 2016;10:208-234. https:// doi.org/10.25143/amhr.2016.X.11

[3] Beck CW. The role of the scientist: The amber trade, the chemical analysis of amber, and the determination of Baltic provenience. J Baltic Stud. 1985;16(3):191-199. http://dx.doi.org/10.1080/01629778500000111

[4] Savkevich SS. Physical methods used to determine the geological origin of amber and other fossil resins; some critical remarks. Phys Chem Minerals. 1981;7:1-4. https://doi.org/10.1007/BF00308192

[5] Teodor ED, Badea GI, Teodor ES. Qvo vadis? Current trends and challenges in succinite and other fossil resins (romanite) studies. In: Wagner-Wysiecka E, Kosmowska-Ceranowicz B, editors. The 23rd seminar on Baltic amber in the kaleidoscope of time Gdansk. The Gdansk International Fair; 2016.

[6] Chubarenko I, Stepanova N. Microplastics in sea coastal zone: Lessons learned from the Baltic amber. Environmental Pollution. 2017;224:243-254. http://dx.doi.org/10.1016/j.envpol.2017.01.085

[7] Olszewski-Strzyżowski DJ, Wendt JA. Historia mistrzostw świata w poławianiu bursztynu [History of the World Championships in amber fishing]. In: Olszewski-Strzyżowski DJ, editor. Amber. Yesterday, today and tomorrow. Gdansk: AWFiS Publishing House; 2018, 19-38. Polish.

[8] Wendt JA, Bogadał-Brzezińska A. Złote runo współczesnych Argonautów - bursztyn jako marka turystyczna w internecie w latach 2009-2018 [The golden fleece of modern Argonauts - amber as a tourist brand on the internet in 2009-2018]. In: Olszewski-Strzyżowski DJ, editor. Amber. Yesterday, today and tomorrow. Gdansk: AWFiS Publishing House; 2018, 109-121. Polish. 
[9] Wendt JA. Bursztyn w sieci jako czynnik rozwoju turystyki [Amber in the network as a factor in tourism development]. In: Hochleitner J, editor. Bursztynowy artefakt a kreowanie turystyki kulturowej [Amber artifact and creation of cultural tourism]. Jantar: Institute of Cultural Tourism; 2010, 125-134. Polish.

[10] Drobiz MV. The contribution of mining to the coast dynamics: a retrospective cartographic analysis of the Primorskoe amber deposit area in Kaliningrad region. Geodesy and Cartography. 2019;63(5):524-532. http://dx.doi. org/10.30533/0536-101X-2019-63-5-524-532

[11] Kostyashova ZV. Istoriya Kaliningradskovo yantarnovo kombinata. 1947-2007 [History of the Kaliningrad Amber Factory. 1947-2007]. Kaliningrad: Publishing house Business contact; 2007. Russian.

[12] Krek A, Ulyanova M, Koschavets S. Influence of land-based Kaliningrad (Primorsky) amber mining on coastal zone. Marine Pollution Bulletin. 2018;131:1-9. https://doi.org/10.1016/j.marpolbul.2018.03.042

[13] Malashenkov BM. Yantarnayaotracl Rosiyskoy Federqacyii i mirovoy rynok yantara. [The Russian federation amber industry and the world amber market]. E-journal. Public Administration. 2018;69:103-126. Russian https://doi. org/10.24411/2070-1381-2018-00059

[14] Matsui VM, Remezova EA, Naumenko UZ. Yantar ukrainskovo Polesa: genezis i prognoz rossypey [Amber of Ukrainian Polesie: genesis and forecast of placers]. 127-129. In: Makhnach AA, editor. Problemy geologyi Belorusyi i smezh nykh territoryi [Problems of geology of Belarus and adjacent territories]. Minsk: story Media Proyekt, 2018. Russian.

[15] Matsui WM, Melnik EW, Efimenko WY. Problemy prognozanovykh promyshlennykh tipov rossypey yantra-sukcinita [Problems of prognosis new industrial types for amber-succinite fields]. Institute of National Academy of Sciences of Ukraine. 2008;1:251-254. Russian.

[16] Srebrodolskiy BI. Mir yantara [Amber World]. Kiev: Naukova Dumka; 1988.

[17] Volchetskaya TS, Malevski HM, Rener NA. The Amber Industry: Development Challenges and Combating Amber Trafficking in the Baltic Region. Balt. Reg. 2017; 9 (4): 114-128. https://doi.org/10.5922/2074-9848-2017-4-6

[18] Malanchuk EZ, Kornyenko VYA, Malanchuk ZR. Perpektyvy Перспективы внедренияновых технологий д обычиянта рявровенской области [Prospects for the introduction of new technologies for the production of amber in the Rivne region]. Geology and Mineralogy Bulletin of KryvyiRih National University.2016; 41: 74-78. Russian.

[19] Moshkov NN. Исцеляющеетеплоянтаря (история, медицина, косметология) [The healing heat of amber (history, medicine, cosmetology)]. Kaliningrad, 2006. Russian.

[20] Hnatushenko VV, Mozgovyi DK, Vasyliev VV, Kavats OO. Satellite monitoring of consequences of illegal extraction of amber in Ukraine Sci. Bull. National Mining University. 2017;2:99-105.

[21] Malanchuk Z, Korniyenko V, Malanchuk Y, Khrystyuk A. Results of experimental studies of amber extraction by hydromechanical method in Ukraine. East-Eur J Enterp Technol. 2016;3(10/81):24-28. https://doi.org/10.15587/17294061.2016.72404

[22] Malka A, Kramarska R. The mining of Baltic amber deposits in Poland - an overview International Amber Researcher Symposium; 2013, 10-16.

[23] Szamalek K. Bursztyn jako surowiec strategiczny [Amber as a strategic source]. Biul Panstw Inst. Geol. 2016;466:291296. https://doi.org/10.5604/01.3001.0009.4326 Polish.

[24] Iturralde-Vinent MA. Geology of the amber-bearing deposits of the greater Antilles. Caribb J Sci. 2001;37(3-4):141-167.

[25] Duffin CJ. Historical survey of the internal use of unprocessed amber. Acta Med. Hist. Adriat. 2015; 13(1): 41-74.

[26] Kaczmarczyk I. Baltic amber in medicine-research on the biological activity of amber. In: Wagner-Wysiecka E, Kosmowska-Ceranowicz B, editors. The 23rd seminar on Baltic amber in the kaleidoscope of time Gdansk. The Gdansk International Fair; 2016.

[27] Tumilowicz P, Synoradzki L, Sobiecka A, Arct J, Pytkowska K, Safarzynski S. Bioactivity of Baltic amber-fossil resin. Polimery. 2016;61(5):347-356. https://doi.org/10.14314/polimery.2016.347

[28] Akopyan VB, Bambura MV, Afonin AV, Filatova VA. Ptotivmikrobnyye zashchinyye pokrytya s yantarom i propolisom [Protective antimicrobial coverings containing amber and propolis]. Izvestiya MGTU MAMI. 2012 ; 2 (14): $262-269$. Russian.

[29] Akopyan VB, Bambura MV, Afonin AV, Sorokin IA. Yantarnoye pokrytya dla predotrashchenya obsrastanya v morkoy wode i biotekhnologichesikh sredakh [Amber coatings to prevent fouling in sea water and biotechnological media]. The proceedings of International research workshop conference Biotechnologies in Comprehensive Regional Development, March 15-17, 2016. Russian.

[30] Akopyan VB, Bambura MV, Dudoragin ES, Kurbatov DG. icpolzovanye yantarnykh pokrytyi dla zashchity medicinskikh izdelyi]. The proceedings of International research workshop conference Biotechnologies in Comprehensive Regional Development, March 15-17, 2016. Russian.

[31] Sorokin IA, Akopyan VB, Bambura MV, Bekesh SG. Zashchitnyi lakot poverkhnostyi obrastanyi podvodnykh obyektov [Protective varnish for underwater objects from fouling]. KSTU NEWS. 2016;42:225-232. Russian.

[32] Mikhaylova AA. In pursuit of an innovation development trajectory of the Kaliningrad region. Balt Reg. 2019;11(3): 92-106. https://doi.org/10.5922/2079-8555-2019-3-5

[33] Gorochnaya VV, Mikhaylov AS, Mikahylova AA, Plotnikova AP. Tourism clusters and innovation security: dialectics in the western border regions of Russia. GeoJournal of Tourism and Geosites. 2020;28(1):127-139. https://doi. org/10.30892/gtg.28110-457 